\title{
TANGGUNGJAWAB PENYEDIA LAYANAN JASA KURSUS MENGEMUDI MOBIL DALAM KECELAKAAN LALU LINTAS
}

\author{
Dyah Merry Ani, I Nyoman Putu Budiartha, I Made Minggu Widyantara \\ Fakultas Hukum, Universitas Warmadewa, Denpasar - Bali, Indonesia \\ budiarthaputu59@gmail.com, mingguwidyantara.fhwjurnal@gmail.com
}

\begin{abstract}
Abstrak
Kursus mengemudi mobil merupakan bimbingan belajar yang terkait keterampilan mengemudi yang bertujuan untuk memberikan pengetahuan cara mengemudi mobil kepada pengguna jasa kursus. Pengguna jasa kursus didampingi dan dilatih oleh Instruktur selama kursus mengemudi berlangsung. Namun, pengguna jasa kursus bersama instruktur akan dihadapkan dengan peristiwa yang tidak terduga, yang kerap terjadi yakni kecelakaan lalu lintas. Tujuan penelitian ini untuk mengungkap hubungan hukum yang terjadi antara penyedia layanan jasa kursus mengemudi mobil dengan instruktur dan juga pengguna jasa kursus serta bentuk tanggung jawab dari penyedia layanan jasa kursus mengemudi mobil jika terjadi kecelakaan pada saat kursus mengemudi berlangsung. Penelitian ini adalah penelitian hukum empiris dengan pendekatan secara yuridis sosiologis dan pendekatan perundang-undangan. Teknik pengumpulan data dilakukan dengan wawancara. Sumber data yang digunakan dalam penelitian ini adalah sumber data primer dan sumber data sekunder. Setelah data dikumpulkan kemudian dianalisis secara sistematis. Hasil penelitian ini menunjukkan bahwa adanya hubungan hukum antara pihak-pihak yang terlibat, yakni hubungan kerja yang terjadi antara instruktur dengan penyedia layanan jasa kursus mengemudi, dan adanya kata sepakat dari pengguna jasa kursus melalui pengisian formulir pendaftaran kursus kepada penyedia layanan jasa kursus mengemudi. Terjadinya kecelakaan lalu lintas pada saat praktek kursus mengemudi berlangsung akan ditanggungjawabkan oleh penyedia layanan jasa kursus mengemudi selaku majikan dan instruktur selaku pendamping atau pelatih pengguna jasa kursus pada saat kursus mengemudi berlangsung.
\end{abstract}

Kata Kunci: Kecelakaan Lalu Lintas, Kursus Mengemudi, Tanggung Jawab

\begin{abstract}
Car driving courses are tutoring related to driving skills that aim to provide knowledge of how to drive a car to course service users. Course service users are accompanied and trained by the instructor during the driving course. However, users of course services with instructors will be faced with unexpected events, which often occur, namely traffic accidents. The purpose of this research is to uncover the legal relationship that occurs between car driving course service providers and instructors and also the course service users form the responsibility of the car driving course service provider if an accident occurs during the driving course. This research is an empirical legal research with a sociological juridical approach and a statutory approach. The data collection technique was done by interview. Sources of data used in this research are primary data sources and secondary data sources. After the data was collected, it was analyzed systematically. The results of this research indicate that there is a legal relationship between the parties involved, namely the working relationship that occurs between the instructor and the driving course service provider, and the agreement from the course service user through filling out the course registration form to the driving course service provider. The occurrence of a traffic accident during the driving course practice will be accounted for by the driving course service provider as the employer and the instructor as a companion or trainer for the course service user during the driving course.
\end{abstract}

Keywords: Traffic Accident, Driving Course, Responsibility

\section{PENDAHULUAN}

Kegiatan Kursus mengemudi mobil merupakan kegiatan bimbingan belajar yang terkait akan keterampilan mengemudikan mobil yang bertujuan memberikan pengetahuan dan keterampilan kepada pengguna jasa kursus mengemudi mobil dalam berlalu lintas agar terampil, disiplin, dan memiliki sikap mental yang baik dalam berlalu lintas. Dalam kegiatan pemberian layanan jasa kursus mengemudi mobil oleh penyedia layanan jasa kepada pengguna jasa kursus mengemudi, tentunya telah melalui perjanjian yang telah disepakati oleh kedua belah pihak, yang diawali dengan 
pendaftaran yang harus dilakukan sebelum memulai pelatihan sebagai pengguna jasa kursus mengemudi.

Pengguna jasa kursus mengemudi disini merupakan orang yang tidak mengetahui dan memahami bagaimana cara mengemudikan mobil dan orang yang memiliki keinginan untuk mengemudikan mobil dengan lancar. Seseorang yang ingin mengikuti kursus mengemudi mobil dapat datang langsung ketempat kursus mengemudi yang dipilihnya dan seseorang tersebut akan melakukan pendaftaran terlebih dahulu, dimana dimulai dengan pengisian keterangan identitas diri pengguna jasa kursus pada buku daftar si pengguna jasa kursus atau formulir pendaftaran kursus yang berisikan Nama, tempat/ tanggal lahir, jenis kelamin, nomor telpon, alamat pengguna jasa kursus/atau biodata yang sesuai dengan identitas diri yang masih berlaku, dan daftar paket harga pembayaran kursus yang dipilih, serta tanda tangan yang dilanjutkan dengan dijelaskannya syarat dan ketentuan kursus secara lisan lalu menentukan jadwal kursus, yang kemudian pengguna jasa kursus akan diberikan selembaran kertas catatan kegiatan kursus.

Dalam praktek kegiatan kursus mengemudi mobil peserta didik atau pengguna jasa kursus mengemudi tidak ditangani langsung oleh pihak penyedia layanan jasa kurus mengemudi tersebut, melainkan ada seorang tenaga pengajar yang disebut instruktur yang ditugaskan oleh pihak penyedia jasa untuk mendampingi peserta didik atau pengguna jasa selama waktu pelatihan kursus mengemudi. Instruktur disini merupakan sebagai orang yang memberikan bimbingan belajar terkait kemahiran dalam mengemudikan mobil, dengan menggunakan mobil latihan kursus mengemudi yang telah dilengkapi dengan tambahan pedal gas dan pedal kopling serta dua rem yang berfungsi sebagai pengontrol oleh seorang instruktur yang berada disamping pengguna jasa sebagai sarana belajar yang guna untuk meminimalkan terjadinya kecelakaan.

Walaupun telah dilengkapi dengan alat-alat tambahan guna mengoptimalkan pembelajaran dan terjadinya kecelakaan lalu lintas, ternyata tidak dapat dikatakan dengan cukup untuk menjamin keselamatan pengguna jasa kursus atau untuk meminimalkan terjadinya kecelakaan pada saat latihan, karena dalam proses kegiatan kursus mengemudi mobil berlangsung, instruktur dan pengguna jasa kursus pasti akan dihadapkan dengan peristiwa yang tidak terduga, yang kerap terjadi yakni terjadinya kecelakaan dijalan raya. Kecelakaan yang terjadi pada saat kursus mengemudi dapat berupa menabrak kendaraan lain yang berada didepan atau dibelakang, yang mengakibatkan terjadinya kerusakan pada mobil kursus mengemudi ataupun kendaraan orang lain yang ditabrak oleh pengguna jasa pada saat kursus mengemudi berlangsung. Terjadinya kecelakaan tersebut mengakibatkan adanya kerugian, dimana kerugian tersebut dapat berupa kerugian materiil dan kerugian imateriil, yang lalu muncul masalah akan siapa pihak yang bertanggung jawab atas kerugian ini. Sedangkan di dalam perjanjian kursus antara penyedia layanan jasakursus mengemudi mobil dengan pengguna jasa kursus sama sekali tidakdicantumkan siapa yang bertanggung jawab dan bagaimana bentukpertanggungjawaban atas kerugian tersebut.

Dalam perjanjian kerja antara instruktur kursus mengemudi mobil dengan penyedia layanan jasa kursus, yang bertanggung jawab sepenuhnya terhadap segala kerugian yang timbul akibat kecelakaan pada saat proses pelatihan kursus mengemudi mobil berlangsung adalah instrukur, dikarenakan disini peran seorang instruktur dalam melatih dan/atau mendampingi pengguna jasa kursus mengemudi sangatlah besar, dimana instruktur dituntut untuk dapat mengantisipasi terjadinya kecelakaan lalu lintas pada saat kursus mengemudi mobil berlangsung. Namun, kedudukan instruktur disini adalahsebagai tenaga kerja atau karyawan/buruhdari penyedia layanan jasa kursus mengemudi yang hanya bekerja pada suatu tempat kursus mengemudi untuk melatih dan/atau mendampingi pengguna jasa kursus mengemudi tersebut, dan si penyedia layanan jasa kursus adalah selaku pemberi kerja atau majikannya, maka pada kenyataannya yang bertanggung jawab untuk segala kerugian yang dialami jika terjadinya kecelakaan bukanlah dari pihak Instrukturnya saja, melainkan si penyedia layanan jasa kursus lah yang harus bertanggungjawab atas kerugian yang muncul jika terjadinya kecelakaan lalu lintas pada saat proses kursus mengemudi mobil tersebut berlangsung.

Permasalahan terkait lalu lintas seperti kemacetan, kecelakaan, pelanggaran lalu lintas dan sebagainya telah menjadi hal umum (Winata \& Jonyanis, 2014). Pada dasarnya ketetapan dalam mengemudikan kendaraan telah diatur dalam pasal 106 ayat (4) yaitu 1) Rambu perintah atau rambu larangan 2) Marka jalan 3) Alat pemberi isyarat lalu lintas 4) Gerakan lalu lintas 5) Berhenti dan parkir Undang-undang Nomor 22 Tahun 2009 tentang Lalu Lintas Dan Angkutan Jalan memiliki pasal-pasal yang mengatur tentang larangan-larangan dan kewajiban bagi pengguna dan 
penyelenggara jalan (Jauhari et al., 2015). Adapun bagi lembaga pelatihan yang melakukan kursus atau pelatihannya dijalan raya atau dijalan umum harus mendapatkan izin dari pemerintah daerah setempat melalui dinas perhubungan dan kepolisian daerah setempat (Raenaldi \& Nyoman Serikat PJ, 2016).

Berdasarkan uraian diatas, maka tujuan penelitian ini untuk mengungkap hubungan hukum yang terjadi antara penyedia layanan jasa kursus mengemudi mobil dengan instruktur dan juga pengguna jasa kursus serta bentuk tanggung jawab dari penyedia layanan jasa kursus mengemudi mobil jika terjadi kecelakaan pada saat kursus mengemudi berlangsung.

\section{METODE PENELITIAN}

Tipe penelitian yang dilakukan pada penelitian ini adalah penelitian hukum empiris. Penelitian hukum empiris merupakan suatu metode penelitian yang menggunakan fakta-fakta empiris yang diambil dari sikap perilaku manusia, yang didapat dari wawancara maupun perilaku nyata yang dilakukan melalui pengamatan langsung. Penelitian hukum empiris ini meneliti secara langsung ke lapangan untuk mengamati keadaan nyata yang ada di masyarakat dan memperoleh sebuah informasi yang nyata (real). Pendekatan masalah yang digunakan pada penelitian ini yakni pendekatan secara yuridis sosiologis dan pendekatan perundang-undangan, dimana pendekatan ini dapat melihat sesuatu kenyataan di dalam masyarakat serta menelaah beberapa peraturan perundang-undangan, yang bertujuan untuk mendapatkan fakta-fakta atau permasalahan yang ada dan akhirnya menuju untuk menyelesaikan masalah yang ada. Teknik pengumpulan data yang dilakukan dalam penelitian ini yakni dengan melakukan wawancara (Interview) secara langsung dengan pihak informan guna mendapatkan informasi secara langsung untuk menguatkan data primer, dan melakukan studi pustaka dengan membaca, menelaah dan mengutip perundang-undang, buku-buku, jurnal, dan literatur, dan/atau menggunakan internet guna menemukan pokok bahasan yang berkaitan dengan permasalahan yang akan dibahas untuk menguatkan data sekunder. Sumber data yang digunakan dalam penelitian ini adalah sumber data primer yang diperoleh dengan cara melakukan wawancara secara langsung dengan informan ataupun responden. Adapun data sekunder merupakan sumber data penjelas yang digunakan untuk menunjang penjelasan dari data primer yang didapat melalui bahanbahan kepustakaan dan/atau Perundang-Undangan guna menemukan pokok bahasan dan/atau teori teori yang relevan dengan permasalahan yang akan dibahas, antara lain: Kitab Undang-Undang Hukum Perdata (KUHPerdata), Peraturan Pemerintah Nomor 44 Tahun 1993 tentang Kendaraan dan Pengemudi, Peraturan Keputusan Menteri Perhubungan Nomor: KM. 36 Tahun 1994 tentang Pendidikan Mengemudi Kendaraan Bermotor, Undang-Undang Nomor 8 Tahun 1999 tentang Perlindungan Konsumen, Undang- Undang Nomor 20 Tahun 2003 tentang Sistem Pendidikan Nasional, Undang-Undang Nomor 22 Tahun 2009 Tentang Lalu Lintas dan Angkutan Jalan. Setelah data dikumpulkan maka selanjutnya dianalisis secara sistematis.

\section{HASIL DAN PEMBAHASAN}

\section{Hubungan Hukum yang Terjadi Antara Penyedia Layanan Jasa Kursus Mengemudi Mobil dengan Instruktur dan Juga Pengguna Jasa Kursus}

Hubungan hukum merupakan hubungan antara dua atau lebih subyek hukum yang terlibat didalamnya. Dalam hubungan hukum ini hak dan kewajiban pihak yang satu akan berhadapan dengan hak dan kewajiban yang lainnya. Tidak semua hubungan merupakan hubungan hukum, karena suatu hubungan hukum harus terdapat dasar hukum yang mengatur didalamnya dan diikuti dengan adanya suatu peristiwa hukum. Didalam layanan jasa kursus mengemudi mobil ini, hubungan hukum antara penyedia layanan jasa kursus mengemudi dengan instruktur adalah hubungan kerja, hubungan kerja tersebut dapat dilihat dengan diadakannya sebuah perjanjian kerja oleh kedua belah pihak yang terlibat didalamnya, yang dimana perjanjian itu merupakan suatu peristiwa hukum yang mengharuskan seorang berjanji kepada orang lain atau dua orang saling berjanji untuk melakukan atau tidak melakukan sesuatu.

Didalam suatu pelayanan jasa kursus mengemudi, dari pihak penyedia layanan jasa kursus mengemudi pasti akan memerlukan atau mencari tenaga kerja dan/atau orang-orang untuk bekerja membantunya, seperti tenaga kerja admin-adminatau pegawai-pegawai yang digunakan dalam bidang penerimaan calon pengguna jasa kursus mengemudi ditempat kursus mengemudi tersebut, dan orang yang dipercayai untuk bertanggung jawab pada satu cabang tempat kursus mengemudi tersebut 
berdiri, serta seorang tenaga kerja pendamping calon pengguna jasa kursus pada saat kursus mengemudi berlangsung yang bisasa disebut Instruktur. Penyedia layanan jasa kursus mengemudi ini adalah seorang yang memberi pekerjaan terhadap orang-orang yang dijelaskan diatas dan sekaligus seseorang yang mempunyai peran penting dalam pendirian dari kursus mengemudi tersebut.Dimana disini pihak penyedia layanan jasa kursus adalah bertindak sebagai majikan atau pemberi kerja, sedangkan instruktur dan admin-admin atau pegawai-pegawai adalah bertindak sebagai tenaga kerja atau pekerja/buruh.

Instruktur secara etimologi berasal dari kata Instruksi yang artinya mengajarkan sebuah pelajaran dan memberikan perintah atau pemahaman. Dimana dari arti tersebut, instruktur merupakan orang yang memberikan sebuah pelajaran, perintah maupun larangan kepada siswanya, yang dalam kasus ini siswa disebut sebagai pengguna jasa kursus mengemudi. Untuk dapat bekerja menjadi seorang instruktur pengemudi mobil, pihak penyedia layanan jasa kursus mengemudi sebelumnya menyeleksi terlebih dahulu orang yang akan melamar menjadi seorang Instruktur, dimana menjadi Instruktur pengemudi mobil pada pelatihan kursus mengemudi harus memiliki Skill terlebih dahulu dan Lisensi pengajar dan/atau sebuah sertifikat pengajar yang dikeluarkan dari pihak kepolisian yang bertujuan untuk dapat menjadi seorang Instruktur yang ahli dalam mengemudikan mobil sehingga dapat mendampingi pengguna jasa kursus dengan baik dan benar serta aman dalam proses kursus mengemudi dijalan, dan juga sekaligus lebih dapat menarik masyarakat yang akan belajar mengemudi dengan mempromosikan bahwa tenaga pengajar dalam layanan jasa kursus mengemudi adalah seorang pengajar atau Instruktur yang professional yang akan mengajari dan/atau mendampingi pengguna jasa kursus pada saat proses kursus mengemudi mobil berlangsung.

Berdasarkan penelitian, dikatakan bahwa antara Instruktur dengan pihak penyedia layanan jasa kursus mengemudi ini tidak ada hitam diatas putih, dimana dimaksudkannya bahwa pihak penyedia layanan jasa kursus mengemudi ini hanya memberitahukan kepada pihak instruktur apa saja yang menjadi aturan-aturan didalam layanan jasa kursus mengemudi tersebut secara langsung atau lisan tidaklah secara tertulis, tidak ada penyerahan atau pemberian selembar kertas apapun terkait dengan peraturan-peraturannya, melainkan hanya dikatakan secara lisan.Untuk menjadi instruktur pendamping pengguna jasa kursus mengemudi mobil ini sebelumnya harus melaksanakan suatu kegiatan latihan atau yang biasa disebut dengan Training selama 3 bulan untuk mendampingi pengguna jasa kursus mengemudi mobil, lalu jika telah dinyatakan baik, memenuhi syarat dan lolos maka akan langsung dipekerjakan untuk menjadi salah satu Instruktur tetap pada tempat layanan jasa kursus mengemudi mobil tersebut.

Didalam kursus mengemudi mobil, hubungan hukum yang terjadi antara penyedia layanan jasa kursus mengemudi mobil dengan pengguna jasa kursus mengemudi mobil yakni dapat dilihat dengan adanya perjanjian yang disepakati oleh kedua belah pihak yang terlibat, dimana perjanjian tersebut dapat dilihat dan/atau ditemukan dalam bentuk formulir pendaftaran yang telah diberikan dari pihak layanan jasa kursus mengemudi dan diisi oleh pengguna jasa kursus mengemudi mobil terlebih dahulu untuk mengikuti kursus mengemudi mobil tersebut. Dimana pihak pengguna jasa kursus mengemudi mobil mengisi lengkap data dirinya sendiri dan memilih paket kursus apa yang akan diinginkannya, dan membaca syarat-syarat yang tertera pada formulir yang diberikan, lalu kemudian menandatanganinya sebagai pernyataan sepakat dan setuju untuk mengikatkan dirinya sebagai siswa belajar atau disebut sebagai pengguna jasa kursus mengemudi mobil pada tempat layanan jasa kursus mengemudi tersebut.

Pengguna jasa kursus mengemudi disini dapat menentukan sendiri paket-paket apa saja yang telah disediakan dari pihak penyedia layanan jasa kursus mengemudi dengan menyesuakian budget atau harga-harga yang setiap paketnya terdapat perbedaan harganya. Pengguna jasa kursus mengemudi disini dapat memilih mobil yang diinginkannya, apakah itu mobil matic ataupun mobil manual yang akan digunakannya dalam mengikuti kursus tersebut. Pada umumnya pihak Instruktur disini guna sebagai pengajar dan/atau pendamping dari pengguna jasa kursus mengemudi telah mengoptimalkan agar tidak terjadinya suatu kecelakaan lalu lintas di jalan raya pada saat kursus mengemudi tersebut berlangsung, namun tidak dapat diduga atau dipungkiri kecelakaan lalu lintas tersebut pasti saja bisa terjadi kapanpun dan dimanapun. Kecelakaan lalu lintas tersebut bisa bersumber dari kelalaian Instruktur itu sendiri, kelalaian pengguna jasa kursus mengemudi (siswa belajar), ataupun dari pihak orang lain yang berada di jalan raya tersebut dan/atau terlibat dalam kecelakaan tersebut, dimana bentuk kelalaian yang dikatakan diatas yakni seperti ketidakseriusan 
pada saat berlatih pleh pengguna jasa kursus mengemudi, kurang focus yang bisa terjadi antara Instruktur dan/atau pengguna jasa kursus mengemudi (siswa belajar) yang mengakibatkan terjadinya kecelakaan, dan banyak faktor lain yang bisa menyebabkan terjadinya kecelakaan lalu lintas pada saat kursus mengemudi berlangsung.

Berdasarkan hasil wawancara yang telah dilakukan, dapat dinyatakan sebesar 0,5\% kecelakaan yang telah terjadi pada saat kursus mengemudi mobil berlangsung, Kecelakaan yang terjadi adalah kecelakaan yang dikategorikan kedalam kecelakaan ringan dan/atau kecelakaan sedang yang telah diatur dalam pasal 229 Undang-Undang Nomor 22 Tahun 2009 tentang Lalu Lintas Angkutan Jalan.

\section{Bentuk Tanggung Jawab dari Penyedia Layanan Jasa Kursus Mengemudi Mobil jika Terjadi Kecelakaan pada Saat Kursus Mengemudi Berlangsung}

Tanggungjawab dari pihak instruktur disini terhadap pengguna jasa kursus mengemudi yakni wajib akan Instruktur untuk berhenti di Tempat Kejadian Perkara (TKP) dan melihat terlebih dahulu bagaimana bentuk kecelakaan yang terjadi serta memastikan bahwa pihak siapakah yang bersalah sehingga dapat menimbulkan kecelakaaan lalu lintas. Pada saat terjadinya kecelakaan lalu lintas Instruktur wajib untuk memberikan bentuk pertanggungjawaban atau menyelesaikannya terlebih dahulu dengan pihak-pihak yang terlibat.

Jika kecelakaan terjadi dari kelalaian pengguna jasa kursus mengemudi (siswa belajar) nya sendiri, maka si Instruktur akan memberikan penjelasan terkait dengan kecelakaan yang terjadi dan meminta pengguna jasa kursus ini untuk ikut bertanggungjawab atau memberikan bentuk pertanggungjawaban yang tetap akan didampingi oleh Instrukturnya dan pasti akan diluruskan oleh sang insturuktur pada saat kecelakaan berlangsung.

Namun jika kecelakaan terjadi karena kelalaian dari Instruktur maka Instruktur yang akan bertanggungjawab atas kecelakaan yang telah terjadi, dan memeriksa kendaraan kursus dan juga kendaraan dari pihak yang terlibat didalam kecelakaan, lalu mengambil tindakan berdasarkan keputusan yang dirundingan sebelumnya dengan pihak yang terlibat apakah patut untuk dibawakan ke tempat service kendaraan (bengkel) atau sebagainya. Penyedia layanan jasa kursus mengemudi merupakan majikan dan/atau orang pemberi kerja terhadap orang-orang yang melamar pekerjaan pada tempat layanan jasa kursus mengemudi yang dimilikinya, dimana dalam mendirikan layanan jasa kursus mengemudi ini, penyedia layanan jasa mengemudi haruslah mengurus berkas-berkas dan mematuhi dan/atau mentaati persyaratan apa saja yang harus dipenuhi untuk mendirikan sebuah layanan jasa kursus mengemudi tersebut.

Dalam bentuk memberi pertanggungjawaban dari pihak penyedia layanan jasa kursus mengemudi terhadap pengguna jasa kursus mengemudi itu sendiri berdasarkan wawancara yang dilakukan yakni, pihak penyedia layanan jasa kursus mengemudi akan memberikan pertanggungjawaban dengan melihat dan mendengar penjelasan dari pihak Instruktur nya terlebih dahulu, lalu dengan pihak pengguna jasa kursus mengemudinya, dan menilai pihak siapakah yang bersalah sehingga memunculkan terjadinya kecelakaan lalu lintas pada saat kursus mengemudi mobil itu berlangsung. Pihak penyedia layanan jasa kursus mengemudi juga tidak akan lepas tangan untuk bertanggung jawab jika sampai terjadinya kecelakaan lalu lintas pada saat proses kursus mengemudi ditempatnya berlangsung.

Pihak penyedia layanan jasa kursus mengemudi mobil disini memberikan bentuk pertanggungjawaban biaya sebesar 50\% jika kesalahan penyebab terjadi kecelakaan lalu lintas ada pada kelalaian dari Instrukturnya, dan tidak menutup kemungkinan untuk memberikan pertanggungjawaban biaya sebesar 70\%-75\% terhadap kecelakaan yang terjadi pada layanan jasa kursus mengemudi miliknya, namun dengan syarat penyedia layanan jasa kursus mengemudi ini harus mengetahui terlebih dahulu alur cerita permasalahan yang mengakibatkan terjadinya kecelakaan lalu lintas tersebut, dan kerusakan apa saja yang diakibatkan dari kecelakaan lalu lintas tersebut.

Pihak penyedia layanan jasa kursus mengemudi disini akan meng-clearkan semua masalah yang terjadi pada layanan jasa kursus mengemudi yang dia miliki termasuk dengan adanya kecelakaan lalu lintas yang terjadi pada saat kursus mengemudi berlangsung di perusahaan layanan jasa kursus mengemudi tempatnya, pihak penyedia layanan jasa kursus tidak akan membebankan semua bentuk pertanggungjawaban kerugian-kerugian yang dialami semua kepada instrukturnya, dikarenakan disini 
instruktur tetap hanyalah seorang pekerja/buruh pada penyedia layanan jasa kursus mengemudi yang merupakan majikannya.

\section{SIMPULAN DAN SARAN \\ 1. Simpulan}

Hubungan hukum yang terjadi antara penyedia layanan jasa kursus mengemudi dengan instruktur adalah hubungan kerja, yang mana hubungan kerja dapat dilihat dengan diadakannya sebuah perjanjian kerja oleh kedua belah pihak yang terlibat didalamnya, instruktur tersebut merupakan pekerja/buruh atau seorang tenaga kerja yang bekerja pada penyedia layanan jasa kursus mengemudi dan si penyedia layanan jasa kursus mengemudi merupakan seorang majikan atau seorang atasan yang memiliki perusahaan layanan jasa kursus mengemudi, dan hubungan hukum antara penyedia layanan jasa kursus mengemudi dengan pengguna jasa kursus atau siswa belajar dapat dilihat dari perjanjian tertulis yang ditemukan pada formulir yang diisi oleh pengguna jasa kursus pada saat mendaftarkan dirinya untuk mengikuti kursus mengemudi pada penyedia layanan jasa kursus mengemudi tersebut. Apabila terjadi kecelakaan lalu lintas pada saat proses kursus mengemudi mobil berlangsung, Instruktur wajib berhenti di Tempat Kejadian Perkara (TKP), memeriksa kendaraan atau mobil kursus, memeriksa pihak lain yang terlibat didalam kecelakaan lalu lintas, dan memastikan siapakah pihak yang bersalah akan terjadinya kecelakaan lalu lintas tersebut, Jika kecelakaan terjadi dikarenakan kelalaian Instruktur dan pengguna jasa kursus atau siswa belajar, Instruktur wajib memberikan bentuk pertanggungjawaban sebesar 50\% atau lebih, dan pihak penyedia layanan jasa kursus mengemudi tetap bertanggung jawab akan kecelakaan selaku sebagai majikan atau penyedia layanan jasa kursus mengemudi yang terlibat, dimana bentuk pertanggungjawabannya adalah dengan memberikan ganti rugi kepada pihak yang terlibat dalam kecelakaan yang terjadi yaitu berupa biaya pengobatan atas kerugian fisik yang ditimbulkan serta biaya perbaikan mobil atau kendaraan kursus.

\section{Saran}

Dalam hal ini Pihak penyedia layanan jasa kursus mengemudi diharapkan untuk membuatkan kontrak kerja yang sah dan tertulis antar tenaga kerja yang bekerja pada layanan jasa kursus mengemudi yang dimiliki guna untuk memiliki suatu perjanjian antara pekerja/buruh dengan pengusaha atau pemberi kerja yang memuat syarat-syarat kerja, hak dan kewajiban para pihak yang sesuai dengan undangundang ketenagakerjaan dan memperhatikan hak-hak tenaga kerjanya yang berdasarkan sesuai dengan Undang-Undang ketenagakerjaan yang tidak hanya menekankan akan kewajiban-kewajibannya saja. Pada pembuat Undang-Undang lalu lintas yaitu Undang-Undang Nomor 22 tahun 2009 diharapkan dapat merevisi pasal 79 ayat 2 dengan lebih menjelaskan secara detail seorang instruktur akan bertanggungjawab pada terjadinya kecelakaan lalu lintas yang disebabkan oleh instruktur atau yang disebabkan oleh pengemudi atau siswa belajar agar lebih jelas kedepannya.

\section{DAFTAR PUSTAKA}

A., D. (2009). Menuju Dunia Kerja dan Wirausaha. Suluh Media, Bandung.

Fajar, M., \& Achmad, Y. (2010). Dualisme Penelitian Hukum Empiris \& Normatif. Pustaka Pelajar, Yogyakarta.

HS, H. S., \& Nurbani, E. S. (2014). Penerapan Teori Hukum pada Penelitian Disertasi dan Tesis. Raja Grafindo Persada, Jakarta.

Ishaq. (2008). Dasar-Dasar Ilmu Hukum. Sinar Grafika, Jakarta.

Jauhari, L., Erdianto, \& Edorita, W. (2015). Pertanggungjawaban Pidana terhadap Calon Pengemudi

Saat Belajar Mengemudi atas Pelanggaran Kecelakaan Lalu Lintas Menurut Undang Undang

Nomor 22 Tahun 2009 tentang Lalu Lintas dan Angkutan Jalan. Jurnal Online Mahasiswa Fakultas Hukum, 2(2), 1-15.

Muhammad, A. K. (2000). Hukum Perdata Indonesia. Citra Aditya Bakti, Bandung.

Muhammad, A. K. (2010). Hukum Perusahaan Indonesia. Citra Aditya Bakti, Bandung.

Raenaldi, A., \& Nyoman Serikat PJ, P. (2016). Pertanggungjawaban Pidana mengenai Lembaga Pelatihan Mengemudi Mobil yang Membahayakan Pengguna Jalan Umum. Diponegoro Law Journal, 5(4), 1-13. 
Sadar, M., Makarao, T., \& Mawadi, H. (2012). Hukum Perlindungan Konsumen di Indonesia. Akademi, Jakarta Barat.

Samsul, I. (2004). Perlindungan Konsumen Kemungkinan Penerapan Tanggung Jawab Mutlak. Universitas Indonesia, Jakarta.

Soeroso, R. (2005). Pengantar Ilmu Hukum. Sinar Grafika, Jakarta.

Triwulan, T., \& Febrian, S. (2010). Perlindungan Hukum bagi Pasien. Prestasi Pustaka, Jakarta.

Yuliadi, W. H. (2014). Undang-undang Lalu Lintas \& Aplikasinya. Dunia Cerdas.

Winata, A. T., \& Jonyanis. (2014). Peran Lembaga Kursus Mengemudi dalam Sosialisasi Peraturan Lalu Lintas terhadap Kedisiplinan Pengemudi Mobil di Pekanbaru (Studi Kursus Pandu). Jurnal Online Mahasiswa Fakultas Ilmu Sosial Dan Ilmu Politik, 1(2), 1-15. 